\title{
Association Between Soluble CD40 Ligand and Hypercholesterolemia in Children and Adolescents
}

\section{Çocuk ve Adölesanlarda Soluble CD40 Ligandı ile Yüksek Kolesterol Düzeylerinin llișkisi}

\author{
Aynur Küçükçongar Yavaş1, Tuba Fatma Eminoğlu2, Ilyas Okur3, Arzu Aral4, Alev Hasanoğlu3, \\ Leyla Tümer3 \\ ${ }^{1}$ Health Ministery Pediatric Hematology and Oncology Training and Research Hospital, Clinic of Pediatric Metabolism, Ankara, Turkey \\ ${ }^{2}$ Ankara University Faculty of Medicine, Department of Pediatrics, Division of Pediatric Metabolism, Ankara, Turkey \\ ${ }^{3}$ Gazi University Faculty of Medicine, Department of Pediatrics, Division of Pediatric Metabolism, Ankara, Turkey \\ ${ }^{4}$ Gazi University Faculty of Medicine, Division of Immunology, Ankara, Turkey
}

\section{ABSTRACT}

Aim: Coronary heart disease is one of the most common causes of death around the world. The pathological process of coronary heart disease like atherosclerosis starts in childhood. During this period thrombosis constitutes a high-risk factor. In this study, we investigated the effect of soluble CD40 ligand (SCD40L) and clotting activation on children and adolescents with hypercholesterolemia.

Materials and Methods: Plasma levels of SCD40L, P-selectin, 8-hydroxy2-deoxyguanosine (8-OHdG), and prothrombin fragment 1+2 [(F) 1+2] were determined in thirty-five hypercholesterolemic patients ( 20 girls and 15 boys; age, median: 13 years) and forty healthy normocholesterolemic subjects (28 girls and 12 boys; age, median: 13 years).

Results: No significant differences were observed between the patient group and controls in terms of age, high-density lipoprotein (HDL) cholesterol, $8-0 H d G, F 1+2(p>0.05)$. However, there were significant differences between the two groups with respect to total cholesterol, low-density lipoprotein (LDL) cholesterol, very LDL cholesterol, triglycerides, SCD40L and P-selectin $(p<0.05)$, which were higher in the patient group than the controls. A positive correlation was observed between sCD40L and P-selectin $(p<0.05)$ in accordance with the Spearman correlation analysis. The correlation coefficients were 0.735 in the patient group and 0.647 in the control group. But there was no significant

\section{ÖZ}

Amaç: Koroner kalp hastalığı tüm dünyadaki ölüm nedenleri arasında önemli bir yere sahiptir. Ateroskleroz gibi koroner kalp hastalığının patolojik süreci çocukluk çă̆ı dönemlerinde başlamakta olup tromboz bu süreçte önemli bir risk faktörüdür. Bu çalışmada hiperkolesterolemili çocuk ve adölesanlarda soluble-CD40 ligand (SCD40L) ile pıhtllaşmayı aktifleştiren faktörlerin etkisi araştııımış̧ır.

Gereç ve Yöntemler:Plazma sCD40L, P-selektin, 8-hidroksi-2-deoksiguanozin (8-OHdG), protrombin fragmanı 1+2 [(F) 1+2] düzeyleri, 35 hiperkolesterolemili hasta (20 kız ve 15 erkek; yaş ortalaması 13 yı) ile 40 sağlıkı kontrol (28 kız, 12 erkek; yaş ortalaması 13 yıl) grubunda değerlendirilmiştir.

Bulgular: Her iki grup arasında yaş, yüksek dansiteli lipoprotein (HDL) kolesterol, 8-OHdG, F1+2 düzeyleri açısından anlamlı farklıık saptanmamıştır $(p>0,05)$. Ancak toplam kolesterol, düşük dansiteli lipoprotein (LDL) kolesterol, çok LDL kolesterol, trigliserit, SCD40L ve P-selektin değerleri gruplar arasında anlamlı olarak farklı olup tüm bu değerler hasta grupta daha yüksek olarak ölçülmüştür $(p<0,05)$. Spearman korelasyon analizine göre, sCD40L and P-selektin arasında pozitif korelasyon saptanmışıı $(p<0,05)$. Korelasyon katsayısı hasta grupta 0,735 ve kontrol grupta 0,647 olarak ölçülmüştür. SCD40L ile toplam kolesterol, LDL-kolesterol, HDL-kolesterol, 
correlation between SCD40L and total cholesterol, LDL-cholesterol, HDLcholesterol, very LDL-cholesterol, triglycerides, 8-OHdG, F1+2 (p>0.05).

Conclusion: We believe that future prospective studies to determine the increase in the level of SCD40L with a larger sample size of a pediatric population with dyslipidemias may be more helpful in predicting the risk of cardiovascular disease.

Keywords: Hypercholesterolemia, atherosclerosis, CD40 ligand

\section{Introduction}

Coronary heart disease (CHD) and atherosclerosis are the common causes of death around the world. The pathological process of $\mathrm{CHD}$ starts in childhood and its clinical effects are generally seen in adult patients. There are a lot of risk factors as underlying mechanisms of atherosclerosis, and one of these factors is hypercholesterolemia. Epidemiologic and clinical trials have provided clear evidence that cholesterol has a role in the occurrence of cardiovascular disorders $(1,2)$. This may be related to enhanced thrombotic risk. Activated platelets adhere to the intact endothelium and induce inflammatory responses locally, which substantially contribute to the early phase of atherosclerosis. It has been seen that patients with hypercholesterolemia have increased urinary excretion of 11-dehydro-thromboxane B2 and elevated platelet response (3). Another study (4) states that the tendency to prothrombotic state is higher when the formation of monocyte tissue factor (TF) is increased, and prothrombin fragment [(F) 1+2] (a marker of thrombin generation in vivo) levels are elevated.

The expression of CD40 ligand (CD40L) is observed on CD4+ T cells, activated platelets, and vascular system cells (endothelial cells (ECs), smooth muscle cells (SMCs) and macrophages) $(5,6)$. The interaction between the CD40L that is expressed on vascular cells, and soluble CD40L (sCD40L) causes inflammatory and prothrombotic responses, resulting in increased atherosclerotic progression $(5,7)$. When CD40 and SCD40L are adhered, TF in SMCs, ECs, and macrophages are over expressed. Thus TF can provide the convertion of factor $X$ to $X a$ on SMCs within the atherosclerotic plaque (8-10). Previous studies demonstrated that oxidative stress plays a major role in the monocyte expression of TF by promoting nuclear factor-kappa-B activation (11). The plasma level of P-selectin, an activation marker of platelets, can reflect the earlier defects of platelets.

To explore the effect of clotting factors in pediatric CHD pathogenesis, we investigated the behavior of SCD40L and clotting activation in children and adolescents with hypercholesterolemia.

\section{Materials and Methods}

\section{Patients and Controls}

Thirty-five hypercholesterolemic patients whose lowdensity lipoprotein (LDL)-cholesterol levels were $>155 \mathrm{mg} / \mathrm{dL}$ çok LDL-kolesterol, trigliserit, 8-OHdG, F1+2 arasında anlamlı korelasyon kurulamamıştır $(p>0,005)$.

Sonuç: Daha geniş dislipidemili çocuk popülasyonunda yapılacak çalışmalarla SCD40L düzeyindeki artışların kardiyovasküler hastalık oluşum riskini belirlemede yardımcı olabileceğini düşünmekteyiz.

Anahtar Kelimeler: Hiperkolesterolemi, aterosklerozis, CD40 ligand

(4 mmol/L) (20 girls and 15 boys; age, median: 13 years, minimum: 4 years, maximum: 18 years) and who had a history of familial hypercholesterolemia, and forty healthy normocholesterolemic subjects (28 girls and 12 boys; age, median: 13 years, minimum: 4 years, maximum: 18 years) were asked to participate in this study. Physical examination showed that none of the patients had any clinical evidence of peripheral vascular or inflammatory diseases. Potential patients with infection, tumor, diabetes, hypertension, hypothyroidism, hypertriglyceridemia, liver or kidney disease were excluded. Other exclusion criteria were, family history of thrombosis, metabolic syndrome, and medication, which might affect inflammatory and thrombotic markers.

The study was approved by the Gazi University Local Ethics Committee (approval number: 015, 21 January 2008) and all patients and their families provided written informed consent.

\section{Blood Samplings}

Peripheral venous blood samples were obtained after a 12-hour fast. The lipid profile (ß-quantification) was analyzed on fresh samples. The subjects whose total cholesterol and LDL-cholesterol were $>95^{\text {th }}$ percentile according to age and sex were accepted as hypercholesterolemic. Total cholesterol and high-density lipoprotein (HDL) levels were determined by colorimetric-spectrophotometric autoanalyzer (Aeroset ${ }^{\circledR}$, Abbott ${ }^{\circledR}$, Illinois, USA) at $500 \mathrm{~nm}$ according to the Trinder reaction. LDL levels were calculated according to the Friedewald formula [Total cholesterol - (HDL + very LDL [VLDL])]. Blood samples were immediately centrifuged at $2000 \mathrm{rpm}$ for $20 \mathrm{~min}$ at $4{ }^{\circ} \mathrm{C}$ and the supernatant was collected and stored at-80 ${ }^{\circ} \mathrm{C}$ until measurement. Plasma levels of sCD40L, sP-selectin, 8-hydroxy-2-deoxyguanosine (8-OHdG), F1+2 were determined using commercial ELISA kits according to the manufacturers' instructions (human sCD40L ELISA, Bender Med, Austria; human sP-selectin ELISA, Bender Med, Austria; 8-hydroxy-2 deoxyguanosine ELISA, Northwest Life Science Specialties, LLC, USA; prothrombin F1+2 ELISA, Dade Behring Inc., USA).

\section{Statistical Analysis}

Statistical analysis was performed with SPSS 11.5 software for Windows (SPSS Inc., Chicago, Illinois). All 
results are expressed as mean, standard deviation, median, minimum and maximum. Kolmogorov-Smirnov test was used to verify that the data were within normal distribution.

Mann-Whitney $U$ test was used for the comparison of the groups. The association of measurements with other biochemical parameters was assessed by the Spearman rank correlation test. A $p$ value of $<0.05$ was considered statistically significant.

\section{Results}

Age and laboratory parameters of the patient and control groups are shown in Table I. No significant differences were observed between the patient group and controls in terms of age, HDL-cholesterol, 8-OHdG, F1+2 ( $p>0.05)$. On the other hand, there were significant differences with respect to total cholesterol, LDL cholesterol, VLDL cholesterol, triglycerides, sCD40L and P-selectin $(p<0.05)$. These values were higher in the patients than the controls. Serum levels of cholesterol and LDL-cholesterol were $308.7 \pm 142.4,243.7 \pm 146.7 \mathrm{mg} /$ $\mathrm{dL}$ in subjects with hypercholesterolemia, and 154.2 \pm 17.3 and $86.8 \pm 17.5$ in those with normocholesterolemia. These differences between the two groups were significant $(p<0.001)$. Compared to subjects with hypercholesterolemia, those with normocholesterolemia had higher values of $\mathrm{sCD} 40 \mathrm{~L}$, as $3.3 \pm 2.8$ and $1.9 \pm 2.3$, respectively $(p=0.004)$. In respect of P-selectin, the levels were 235.6 \pm 73.5 in hypercholesterolemic subjects and $209.3 \pm 96.1$ in normocholesterolemic subjects ( $p=0.0049)$.

A positive correlation was observed between SCD40L and P-selectin $(p<0.05)$ (Spearman correlation analysis) (Figure 1). Correlation coefficients were 0.735 in the patient group, and 0.647 in the control group. But there was no significant correlation between $\mathrm{SCD} 40 \mathrm{~L}$ and total cholesterol, LDLcholesterol, HDL-cholesterol, VLDL-cholesterol, triglycerides, 8-OHdG, F1+2 (p>0.05) (Table II).

\section{Discussion}

This study provides evidence that, increased SCD40L and P-selectin levels, which are known as inflammatory molecules, are involved in the onset and progression of atherosclerotic disease in children with hypercholesterolemia.

Hypercholesterolemia, a risk factor for cardiovascular disease, is associated with inflammation and hypercoagulability. Thrombophilia is a frequent occurrence in patients with hypercholesterolemia, and can precipitate cardiovascular events in this setting.

Thrombophilia is basically characterized by platelet hyperactivation and up-regulation of TF with enhanced thrombin generation $(3,4)$. CD40L may represent an important link between platelet activation and TF expression (5). It has been reported in a study (12) that, considerable increase in sCD40L would help the prediction of probable cardiovascular events problems in healty women. Another study (13) shows that, higher SCD40L would result in recurrent cardiovascular morbidity and mortality because of acute coronary syndromes. In patients with hypercholesterolemia, CD40L is up-regulated on the platelet surface and (14) may therefore represent an important stimulus for TF expression and clotting activation. It has been shown that, there is a significant correlation between $\mathrm{SCD} 40 \mathrm{~L}$ and prothrombin

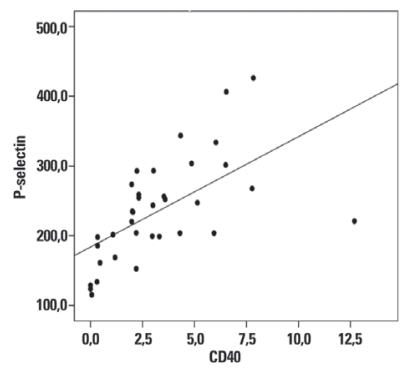

Hypercholesterolemic patients

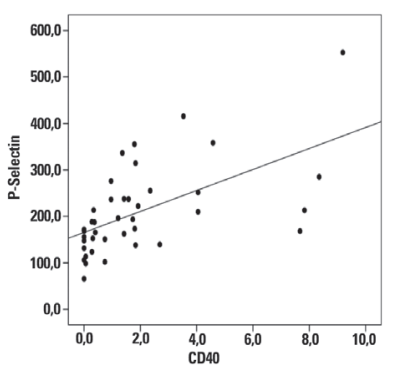

Healthy subjects
Figure 1. Correlations between CD40 and P-selection

\begin{tabular}{|c|c|c|c|c|c|c|c|}
\hline \multirow[t]{2}{*}{ Parameters } & \multicolumn{3}{|c|}{ Hypercholesterolemic patients $(n=35)$} & \multicolumn{3}{|c|}{ Healthy subjects $(n=40)$} & \multirow[t]{2}{*}{$p$} \\
\hline & $\overline{\mathbf{X}} \pm S D$ & Med & (Min-Max) & $\overline{\mathbf{X}} \pm$ SD & Med & (Min-Max) & \\
\hline Age (year) & $12.5 \pm 3.5$ & 13.0 & $(4.0-18.0)$ & $12.4 \pm 3.5$ & 13.0 & $(4.0-18.0)$ & 0.969 \\
\hline Total cholesterol (mg/dL) & $308.7 \pm 142.4$ & 252.0 & $(220.4-704.8)$ & $154.2 \pm 17.3$ & 153.4 & $(118.0-188.0)$ & $<0.001$ \\
\hline LDL-cholesterol (mg/dL) & $243.7 \pm 146.7$ & 175.0 & $(160.0-657.0)$ & $86.8 \pm 17.5$ & 88.8 & $(50.0-122.6)$ & $<0.001$ \\
\hline HDL-cholesterol (mg/dL) & $46.5 \pm 10.3$ & 47.5 & $(25.0-71.0)$ & $51.2 \pm 10.5$ & 50.5 & $(36.0-85.0)$ & 0.130 \\
\hline VLDL-cholesterol (mg/dL) & $20.7 \pm 8.5$ & 19.8 & $(9.4-49.0)$ & $17.8 \pm 13.2$ & 13.3 & $(6.6-89.8)$ & 0.013 \\
\hline Triglycerides (mg/dL) & $103.0 \pm 42.0$ & 95.0 & $(47.0-245.0)$ & $80.5 \pm 32.9$ & 66.5 & $(33.0-175.0)$ & 0.009 \\
\hline $\mathrm{CD} 40$ & $3.3 \pm 2.8$ & 2.3 & $(0.0-12.7)$ & $1.9 \pm 2.5$ & 1.3 & $(0.0-9.2)$ & 0.004 \\
\hline P-selectin & $235.6 \pm 73.5$ & 233.8 & $(115.4-426.3)$ & $209.3 \pm 96.1$ & 188.0 & $(65.8-552.6)$ & 0.049 \\
\hline $8-\mathrm{OHdG}$ & $8176.0 \pm 36160.7$ & 2077.5 & (1519.3-215992.0) & $2058.4 \pm 212.3$ & 2097.5 & $(915.5-2287.5)$ & 0.675 \\
\hline $\mathrm{F} 1+2$ & $719.6 \pm 304.6$ & 643.6 & $(286.4-1490.2)$ & $838.5 \pm 377.4$ & 714.3 & $(422.6-2159.9)$ & 0.181 \\
\hline
\end{tabular}


F1+2 (15). Because CD40L exerts a prothrombotic effect through overexpression of $\mathrm{TF}$, it would be reasonable to speculate that in hypercholesterolemia, clotting activation occurs as a consequence of CD40L overexpression.

This current study aimed to measure the plasma levels of SCD40L and other parameters in children with hypercholesterolemia. Although there are numerous similar studies of adults with hypercholesterolemia, measuring SCD40L concentrations in children with hypercholesterolemia is quite novel. According to our results, SCD40L was significantly higher in hypercholesterolemic patients than the normocholesterolemic control group in childhood. Of course it is important to follow this parameter and the clinical condition of all the subjects in the future for the possibility of coronary syndrome. So we can speculate that this SCD40L parameter can be an indicator to screen the CHD in childhood.

P-selectin is an adhesion molecule known to be involved in the pathogenesis of athero-thrombosis. Being the primary adhesion molecule in initiating cell activation and cell adhesion to platelets, leucocytes and ECs, it's believed that P-selectin may contribute to endothelial dysfunction, atherosclerosis and thrombosis (16). One research showed that, increased levels of soluble P-selectin with higher levels of cholesterol in obese children, might indicate EC damage and platelet activation (17). In our study, P-selectin level was higher in the hypercholesterolemic patients. Additionally a positive correlation between SCD40L and P-selectin was found. As well as being mediators of inflammation and having a significant effect on atherosclerosis, high levels of P-selectin can be a risk factor for CHD. $8-\mathrm{OHdG}$ is a product of oxidative deoxyribonucleic acid (DNA) damage following specific enzymatic cleavage after 8-hydroxylation of the guanosine base. In recent years, $8-\mathrm{OHdG}$ has been

\begin{tabular}{|l|l|l|l|l|}
\hline \multicolumn{5}{|l|}{ Table II. Correlations between CD40 and other parameters } \\
\hline Parameters & \multicolumn{3}{|l|}{$\begin{array}{l}\text { Hypercholesterolemic } \\
\text { patients ( } \mathbf{n}=35)\end{array}$} & \multicolumn{2}{l|}{$\begin{array}{l}\text { Healthy subjects } \\
\text { (n=40) }\end{array}$} \\
\cline { 2 - 5 } & $\begin{array}{l}\text { Spearman } \\
\text { rho }\end{array}$ & $\mathbf{p}$ & Spearman rho & $\mathbf{p}$ \\
\hline $\begin{array}{l}\text { Total cholesterol } \\
\text { (mg/dL) }\end{array}$ & -0.015 & 0.932 & 0.237 & 0.142 \\
\hline $\begin{array}{l}\text { LDL-cholesterol } \\
\text { (mg/dL) }\end{array}$ & -0.096 & 0.584 & 0.120 & 0.461 \\
\hline $\begin{array}{l}\text { HDL-cholesterol } \\
\text { (mg/dL) }\end{array}$ & -0.184 & 0.290 & -0.073 & 0.657 \\
\hline $\begin{array}{l}\text { VLDL-cholesterol } \\
\text { (mg/dL) }\end{array}$ & 0.126 & 0.472 & 0.267 & 0.096 \\
\hline Triglycerides (mg/dL) & 0.059 & 0.735 & 0.202 & 0.210 \\
\hline P-selectin & 0.735 & $<0.001$ & 0.647 & $<0.001$ \\
\hline 8-OHdG & 0.119 & 0.495 & 0.021 & 0.898 \\
\hline F1+2 & -0.086 & 0.624 & 0.098 & 0.546 \\
\hline $\begin{array}{l}\text { rho: Correlation coefficients, LDL: Low-density lipoprotein, HDL: High-density } \\
\text { lipoprotein, VLDL: Very low-density lipoprotein, 8-0HdG: 8-hydroxy-2-deoxyguanosine, } \\
\text { F: Fragment }\end{array}$ & & & \\
\hline
\end{tabular}

used widely in many studies not only as a biomarker for the measurement of endogenous oxidative DNA damage but also as a risk factor for many diseases including cancer and some degenerative diseases (18). According to our findings, there was no significant difference in the $8-\mathrm{OHdG}$ levels of the hypercholesterolemic children compared to the control group. In a previous study, it was shown that the level of $8-\mathrm{OHdG}$ was lower in hypercholesterolemic and normocholesterolemic children than in adults correspondingly (19). This result can be explained by the fact that age is associated with changes of mechanisms controlling oxidative stress and platelet activation. Therefore, our result can be related to the age of the participants. However, in that study (19) there was a significant correlation between the sCD40 and $8-\mathrm{OHdG}$ levels in both hypercholesterolemic children and the adult group. In our study, we couldn't find a positive correlation between those parameters. We may explain this result with the limited number of patients in the study population.

$\mathrm{F} 1+2$, which comes from in vivo cleavage of prothrombin by factor $\mathrm{Xa}$, is considered to be useful for the diagnosis of thrombosis (20). Increased F1+2 levels have been reported in venous thromboembolism, inflammation, cancer, sepsis, acute coronary syndromes, stroke, peripheral arterial disease, atrial fibrillation, and during the postoperative period. In our study, no relation was found in the $\mathrm{F} 1+2$ levels between the patient and the control groups. This result may relate to the differences of the coagulation characteristics in the pediatric population, as variability of these parameters in pediatric population are yet unknown.

In this study, we measured the levels of sCD40L in hypercholesterolemic patients as higher than the healthy control group, which is in accordance with the previous studies $(13-15,21)$. P-selectin levels were higher in the hypercholesterolemic patients than the controls. The expression of CD40 is observed on various cell types such as: ECs, SMCs, macrophages and activated T lymphocytes. The engagement of CD40 and SCD40L triggers atherosclerosis. The expression of vascular cell adhesion molecule-1, intercellular adhesion molecule-1, and P-selectin on ECs facilitate the participation of monocytes and lymphocytes in the injury. Like sCD40L, interleukin (IL)-1, IL-6, and tumor necrosis factor-alpha may have a role in this process. The production of reactive oxygen species are elevated with regard to the CD40-SCD40L engagement, which induces the inhibition of endothelial nitric oxide, causing endothelial dysfunction and promoting atherogenesis $(22,23)$. It is a well-known fact that the degree of the plasma level of cholesterol is directly related to the damage of vascular ECs. This study showed an elevated level of sCD40L in the hypercholesterolemic patients compared to the healthy controls. It was also shown that there was a positive correlation between the level of SCD40L and the level of P-selectin. Therefore, we can speculate that if one of these parameters is normal in range, the other facilitator factor 
might be decreased. Another important aspect of this study is that the participitants were selected from childhood and the adolescent period. To our knowledge, there are very few studies in the literature that lead to the understanding of the mechanism of premature atherogenesis among children.

\section{Study Limitations}

The sample size for the patient group was small.

\section{Conclusion}

In conclusion, future prospective studies with a larger sample size might better detect the increased sCD40L level in the setting of a pediatric population with familial dyslipidemias, which may be more helpful in predicting the risk of cardiovascular events.

\section{Ethics}

Ethics Committee Approval: The study was approved by the Gazi University Local Ethics Committee. (Approval number: 015, 21 January 2008), Informed Consent: Consent form was filled out by all participants.

Peer-review: Internally peer-reviewed.

\section{Authorship Contributions}

Concept: Alev Hasanoğlu, Design: Leyla Tümer, Data Collection or Processing: Aynur Küçükçongar Yavaş, Analysis or Interpretation: Arzu Aral, Literature Search: Ilyas Okur, Fatma Tuba Eminoğlu, Writing: Aynur Küçükçongar Yavaş.

Conflict of Interest: No conflict of interest was declared by the authors.

Financial Disclosure: The authors declared that this study received no financial support.

\section{References}

1. Castelli WP, Anderson K. A population at risk. Prevalence of high cholesterol levels in hypertensive patients in the Framingham Study. Am J Med 1986;80:23-32.

2. Iso $H$, Jacobs DR Jr, Wentworth $D$, Neaton JD, Cohen JD. Serum cholesterol levels and six-year mortality from stroke in 350,977 men screened for the multiple risk factor intervention trial. N Engl J Med 1989;320:904-10.

3. Davi G, Averna M, Catalona I, et al. Increased thromboxane biosynthesis in type Ila hypercholesterolemia. Circulation 1992;85:1792-8.

4. Ferro D, Basili S, Alessandri C, Mantovani B, Cordova C, Violi F. Simvastatin reduces monocyte-tissue-factor expression type Ila hypercholesterolemia. Lancet 1997;350:1222.

5. Henn V, Slupsyk JR, Grafe M, et al. CD40 ligand on activated platelets triggers an inflammatory reaction of endothelial cells. Nature 1998;391:591-4.
6. Schönbeck U, Libby P. The CD40/CD154 receptor/ligand dyad. Cell Mol Life Sci 2001;58:4-43.

7. Lindmark E, Tenno T, Siegbahn A. Role of platelet P-selectin and CD40 ligand in the induction of monocytic tissue factor expression. Arterioscler Thromb Vasc Biol 2000;20:2322-8.

8. Hathcock J. Vascular biology-the role of tissue factor. Semin Hematol 2004;41(1 Suppl 1):30-4.

9. Schoenbeck U, Mach F, Sukhova GK, et al. CD40 ligation induces tissue factor expression in human vascular smooth muscle cells. Am J Pathol 2000;156:7-14.

10. Mach F, Schoenbeck U, Libby P. CD40 signaling in vascular cells: a key role in atherosclerosis? Atherosclerosis 1998;137 Suppl:S89-95.

11. Bowie A, O'Neill LA. Oxidative stress and nuclear factorkappaB activation: a reassessment of the evidence in the light of recent discoveries. Biochem Pharmacol 2000;59:1323.

12. Schonbeck U, Varo N, Libby P, Buring J, Ridker PM. Soluble $\mathrm{CD} 40 \mathrm{~L}$ and cardiovascular risk in women. Circulation 2001;104:2266-8.

13. Heeschen C, Dimmeler S, Ham CW, et al. Soluble CD40 ligand in acute coronary syndromes. $N$ Engl $\mathrm{J}$ Med 2003;348:1104-11.

14. Garlics CD, John S, Schmeisser A, et al. Upregularion of CD40 and CD40 ligand (CD154) in patients with moderate hypercholesterolemia. Circulation 2001;104:2395-400.

15. Sanguigni $V$, Ferro D, Pignatelli P, et al. CD40 ligand enhances monocytes tissue factor expression and thrombin generation via oxidative stres in patients with hypercholesterolemia. $J$ Am Coll Cardiol 2005;45:35-42.

16. Blann AD, Nadar SK, Lip GY. The adhesion molecule P-selectin and cardiovascular disease. Eur Heart J 2003;24:2166-79.

17. Gallistl S, Sudi KM, Borkenstein M, Weinhandl G, Zotter $\mathrm{H}$, Muntean W. Correlation between cholesterol, soluble P-selectin, and D-dimer in obese children and adolescents. Blood Coagul Fibrinolysis 2000;11:755-60

18. Valavanidis A, Vlachogianni T, Fiotakis C. 8-hydroxy-2' -deoxyguanosine (8-OHdG): A critical biomarker of oxidative stress and carcinogenesis. J Environ Sci Health C Environ Carcinog Ecotoxicol Rev 2009;27:120-39.

19. Martino F, Pignatelli $P$, Martino $E$, et al. Early increase of oxidative stress and soluble CD40L in children with hypercholesterolemia. J Am Coll Cardiol 2007;49:1974-81.

20. Páramo JA. Prothrombin fragments in cardiovascular disease. Adv Clin, Chem 2010;51:1-23.

21. Sanguigni $V$, Pignatelli $P$, Lenti $L$, et al. Short-Term Treatment With Atorvastatin Reduces Platelet CD40 Ligand and Thrombin Generation in Hypercholesterolemic Patients. Circulation 2005;111:412-9.

22. Watanebe $M$, Sangawa $A$, Sasaki $Y$, et al. Distrubution of inflammatory cells in adventia changed with advencing atherosclerosis of human coronary artery. J Atheroscler Thromb 2007;14:325-31.

23. Ueland T. Aukrust P, Yndestad A, et al. Soluble CD40 ligand in acute and chronic heart failure. Eur Heart J 2005;26:1101-7. 